\title{
A Ptolemaic Stela of Hor in the Egyptian Museum Cairo
}

\author{
Mohammed A. Elsayed \\ Mas02@fayoum.edu.eg \\ Lecturer, Faculty of Archaeology, Fayoum university, Egypt
}

\begin{abstract}
The goal of this paper is to publish and study a funerary round-topped stela, nowadays stored in the Egyptian Museum in Cairo (CG 22134) ${ }^{1}$. It was owned by the deceased Hor. In 1885, it was discovered by the French Egyptologist G. Maspero under the auspices of the French Mission in the ancient Necropolis of AlHawawish at $\mathrm{Akhmim}^{2}$. Based on the typology, orthography and stylistic features it could be dated to the first half of the second century $\mathrm{BC}^{3}$.
\end{abstract}

KEYWORDS: Funerary stela, Al-Hawawish, Akhmim, Greco-Roman Period, Book of the Dead.

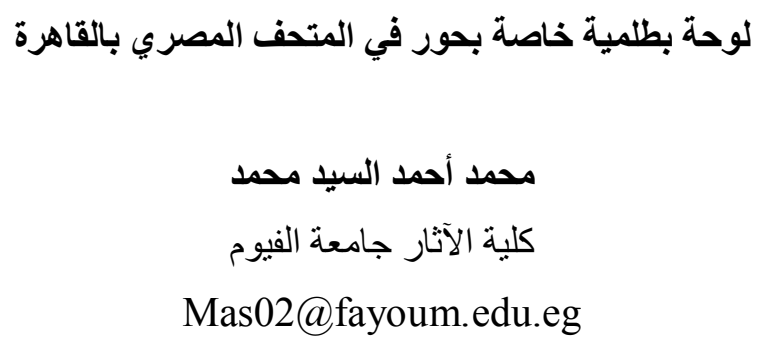

$$
\begin{aligned}
& \text { الملخص: تهدف هذه الدراسة إلى نشر ودراسة أحد اللوحات الجنائزية والمحفوظة حاليًا بالدتحف المصرى } \\
& \text { بالقاهرة تحت رقم (CG 22134) والتى تخص المتوفى حور، والتى نم الكثف عنها بواسطة عالم المصريات }
\end{aligned}
$$

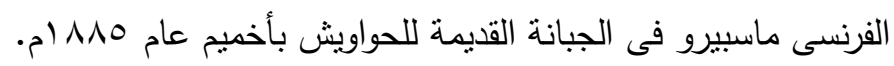

$$
\begin{aligned}
& \text { واستتادا الى نظام الكتابة واسلوب التهجئة والخصائص الفنية بككنا تأريخها بالنصف الأول من القرن الثانى } \\
& \text { ق.م. } \\
& \text { الكلمات الدالة: لوحة جنائزية، الحواويش، أخميم، العصر اليوناني، كتاب الموتى. }
\end{aligned}
$$

\footnotetext{
${ }^{1}$ I would like to express my deepest thanks to the Director of the Egyptian Museum for permission to publish this Stela.

${ }^{2}$ A.Kamal, Catalogue général des antiquités égyptiennes du Musée du Caire $N^{\circ} 2200122208$ Stèles ptolémaïques et romaines, T. I, Texte, (Cairo: IFAO, 1905), I-II.

${ }^{3}$ See for the typology, P. Munro, Die spätägyptischen Totenstelen, ÄgForsch 25, vol. I, (Germany: Verlag J.J. Augustin, Gluckstadt, 1973), 132-141.
} 
This stela is made of limestone with medium state of preservation. Its height is $0,76 \mathrm{~cm}$ and its thickness is $0,41 \mathrm{~cm}$. Both the relief scenes and hieroglyphic inscripitions are incised in sunken relief. The winged sun-disk with two pendent uraei hanging from each side decorate the upper round-topped section ${ }^{1}$. Beneath the lunette is a scene that shows two recumbent jackals facing each other's upon the sign of the $\mathrm{sky}^{2}$. The artistic details are not performed as well, the right one is slightly swollen the head, the neck and the chest. One vertical incised line frames the main scene and the 10 vertical columns of hieroglyphs on each side. On the register and beneath the lunette is a scene shows the stela's owner facing left wearing a long skirt ${ }^{3}$, his hair looks like a cap in a cut shape ${ }^{4}$ with both arms raised in the adoration attitude. Facing the deceased is a slender offering table with a primary sketch of a vessel and of flower ${ }^{5}$. Across it four standing deities ${ }^{6}$ are shown: Osiris, Anubis, Isis and Nephthys. Osiris is standing wearing a tight-fitting garment in mummiform style ${ }^{7}$ with the false beard and the Atef crown. The crook and the flail were left without incised. Behind him Anubis wears a short kilt and holds the usual wAs-sceptre in his left hand while his right was left without grasping the anx-sign. Behind him Isis wears a long tightfitting dress reaching to mid-calf and holds the wAD-scepter in her left hand while her right was left without holding the anx-sign. Behind her Nephthys ${ }^{8}$ with the same artifice details except her symbol on her head [ fig1,2]. The bottom part contains a text in 10 vertical columns of hieroglyphs depicting the adoration of the sunrise through the $15^{\text {th }}$ chapter of the Book of the Dead, versions $15 \mathrm{a}$ and $15 \mathrm{~b}$, running from right to left. Some of the texts are completely worn away in different places, the beginnings and ends of the columns have been damaged; the extensive damage seems to have existed after Kamal transcribed the texts ${ }^{9}$.

Here two goals are behind this work. The first one is to offer a new version of this chapter throughout the publication of this stela. The second one is to provide an analytical study by comparing the current text of this chapter and the other hieroglyphic versions that are existed on eleven stelae from $\mathrm{Akhmim}^{10}$ and four

\footnotetext{
${ }^{1}$ Note that the usual titles of the winged sun-disc Bhdty $n \underline{t r}{ }^{3} \mathrm{nb} p t$ are left.

${ }^{2}$ The sky sign is sometimes decorated with stars, see Stele London BM EA 711; CG 22151. It seems that the part between the winged sun-disc and the two recumbent jackals was left unfinished by neglecting the additional stones without evacuation.

${ }^{3}$ This kilt is quite common on other Ptolemaic stelae, see for example, A.Kamal, Catalogue général des antiquités égyptiennes, CG.22077, P1.XXV.22122.

${ }^{4}$ For a close parallel see B.Bothmer, "A New Fragment of an Old Palette", JARCE, 8 (1969): 5.; E.R. Russman, The Representation of the King in the XXVth Dynasty, (Brooklyn: Bruxelles, Fondation égyptologique Reine Élisabeth, 1974), 29-33.

5 For a close parallel see BM 10558; BM 10826; BM \# 225 quoted from M.Mosher, The Book of the Dead, Saite through Ptolemaic Periods: A Study of Traditions Evident in Versions of Texts and Vignettes, Volume 1 (BD Spells 1-15), (United States: CreateSpace Independent Publishing Platform, 2017), 459 .

${ }^{6}$ This is an usual form of the late Period attitude see, Lichtheim, M., "The Stela of Taniy CGC 20564: Its Date and its Character", $\boldsymbol{S A K}, 16$ (1989):205.

${ }^{7}$ For the substitution of Osiris for Re-Horakhty and the explanation behind that see, Mosher, M., The Book of the Dead, 2016, 458.

${ }^{8}$ For the presence of both Isis and Nephteth in this chapter see, Berlin 3039, BM 10045, BM, 10316, quoted from Mosher, M., The Book of the Dead, 460, note 10.

${ }^{9}$ In the following text, I provide the current state adding the additional texts copied by kamal in the textual notes.

${ }^{10}$ CG, 22025; CG 22070; CG 22144; CG 22147; CG 22148; CG 22149; Stele Berkeley California 86 (Nr. 6-19880); Stele London BM EA 1018.
} 
sarcophagus from Thebes ${ }^{1}$ dated back from the Saite period down to the end of the Greco-Roman Period. I aim to survey and examine the traditions and the developments happened in this chapter by the variations and modifications attested in the different versions reached to the Ptolemaic Period ${ }^{2}$.

\section{The Main Text}

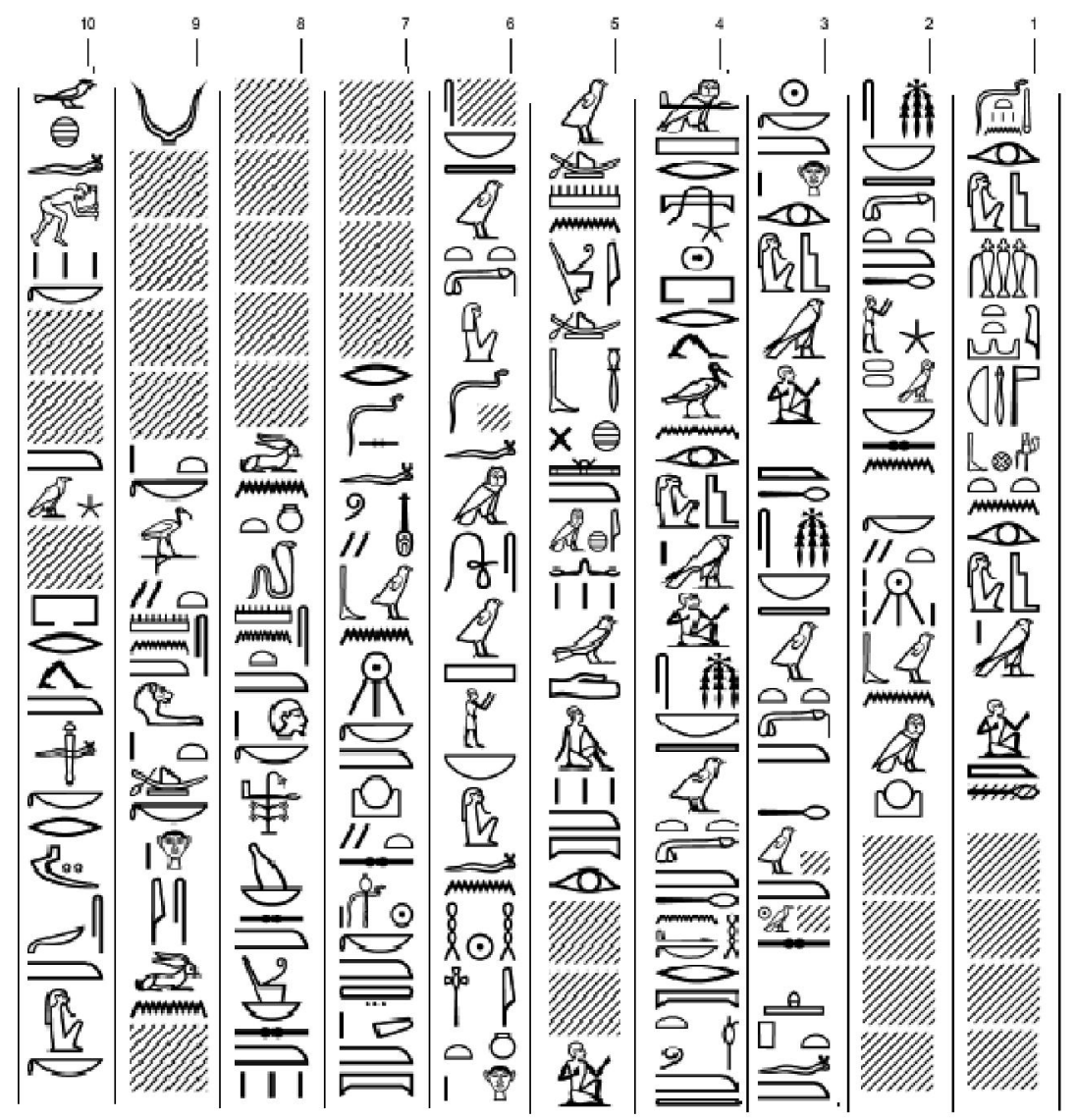

1- $\underline{d} d m d w(i) n$ wsir hnty imntt ntr $93 n b 3 b d w n$ wsir Hr $m 3^{\top}$ hrw

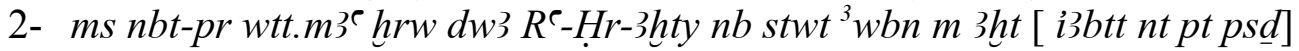

3- .k $m$ hr wsir Hr m3e hrw ms nbt-pr wtt m3e hrw [dw3] tw m dw3w shtp fm

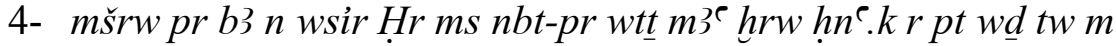

5- wi3 mni [m sktt] 3bh m ihmw wrd m pt w[sir Hr]

6- $[m] s$ nbt-pr wtt $\underline{d}[d]$.f $m$ sw3š $n b . f n n h h$ ind $h r$

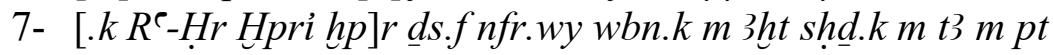

8- [M stwt.k ntrw nbw m hִ؟ m33.sn nswt nb] wnwt smn.t $m$ tp.k šm ${ }^{\top}$ t.s mhw.s $m$

9- Wpt[.kir.s st.s $m$ ḩ] t.k $\underline{d}$ hwty $\operatorname{smn}(w) m$ ḩ3t wỉ.k hr swnw

10-hftyw.k [imyw] $m$ dw3t $\operatorname{pr}(w) m$ hsf.k $r$ m33 sšm.k.

1- Recitation by Osiris, Foremost of the West ${ }^{(a)}$, great god, Lord of Abydos ${ }^{(\mathrm{b})}$ to Osiris, Hor ${ }^{(\mathrm{c})}$, true of voice,

2- born of lady of the house ${ }^{(\mathrm{d})}$ Weteth $^{(\mathrm{e})}$, true ${ }^{(\mathrm{f})}$ of voice, adoring Re-Horakhty, Lord of rays $^{(\mathrm{g})}$, who rises [in the eastern horizon of the sky, may you shine] ${ }^{(\mathrm{h})}$

\footnotetext{
${ }^{1}$ CG 41001, CG 41002, CG 41017, CG 41042.

2 See, Mosher, M., The Book of the Dead, 311- 468.; For more review see: http://totenbuch.awk.nrw.de/account/registrieren.

${ }^{3}$ This writing is only of Greco-Roman Period. See WB, IV, 331 (5-6).
} 
3- on the face of Osiris ${ }^{(i)}$, Hor, true of voice, born of lady of the house Weteth, true of voice, as he [adores] ${ }^{(\mathrm{j})}$ you in the morning and that he propitiates in

4- the evening, may the $b a$ of Osiris Hor born of lady of the house Wetet, True of voice, go forth ${ }^{(\mathrm{k})}$ with you in the sky, that he may command in the sacred-bark ${ }^{(1)}$,

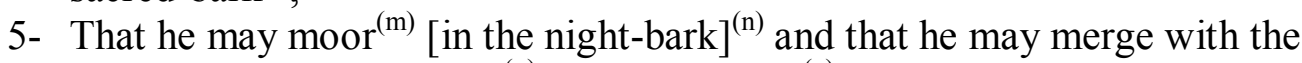
unwearing stars in the sky ${ }^{(\mathrm{o})}$ Osiris, [Hor] $]^{(\mathrm{p})}$

6- born to lady of the house Wetet, he says honouring his lord of eternity, Hail to you

7- [Re-Hor, Khepri who came into being ${ }^{(\mathrm{q})}$ by himself ${ }^{(\mathrm{r})}$, how beautiful is your rising in the horizon when you illuminate in the land and in the sky

8- $\quad$ [with your rays ${ }^{(\mathrm{s})}$, all gods are in rejoicing when they see the king of all, the ${ }^{(\mathrm{t})}$ ] uraeus is fixed on your head ${ }^{(\mathrm{u})}$, Upper Egyptian crown and Lower Egyptian crown on

9- $\left[\right.$ your brow, she makes her place on your forehead $\left.{ }^{(\mathrm{v})}\right]$, Thoth is fixed in front of your sacred bark punishing

10- your enemies ${ }^{(\mathrm{w})}$, $\left[\right.$ who are $\left.{ }^{(\mathrm{x})}\right]$ in the Underworld who have gone out to receive you at your approach to see your image ${ }^{(y)}$.

\section{Textual Notes}

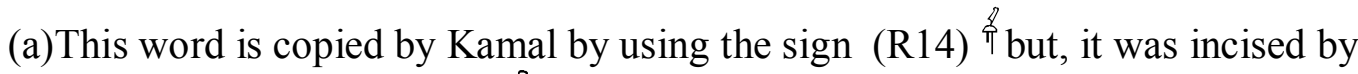
the enlarging feather (H6) $h_{\text {in }}$ the original text.

(b) The sign (U23) ${ }^{T}$ has been mistakenly transcribed by Kamal for the sign (R18A) 照. This writing style is one of the important criteria of the GrecoRoman orthography ${ }^{1}$.

(c)The owner's name occurred four times with two varied orthographies as: It is a common name from the Middle Kingdome to the end of Greco-Roman Period ${ }^{2}$.

(d) This sign has been mistakenly incised for the sigh $(\mathrm{O} 1) \square$.

(e)In the Original text, the owner mother's name is provide without a coil rope (V1) $९$. This sign is given by Kamal depending on the columns 3,4 and 5 . Interestingly it occurred four times with three orthographies as: Also it was only attested during the Greco-Roman period ${ }^{4}$.

(f) This sign has been mistakenly incised for the sigh (Aa11) $=$.

(g) This is a Greco-Roman variation of the word $s t w t^{5}$.

(h) This completion is given by Kamal in his catalogue as: [ [9 now completely destroyed.

(i) Some differences of this introductory line can be noted:

- I I $R^{\top} n b$ stwt wbn $m$ 3ht ỉ $3 b t t n$ pt psd.k $m$ hr $n$ wsir $N N^{6}$.

- I I R nb stwt wbn m 3ht i3bty ntrr ${ }^{\top 3}$ ps $m$ m hr $n$ wsir $N N^{7}$.

\footnotetext{
${ }^{1}$ See Wb, I, 9 (1).

2 see H.Ranke, Die ägyptischen Personennamen, I, (German, Glückstadt: J.J. Augustin, 1935), 242.

${ }^{3}$ This writing is suggested by Kamal and not existed on the orginal.

${ }^{4}$ Ranke, Die ägyptischen Personennamen, 88.3.

${ }^{5}$ See WB, IV, 331 (5-6).

${ }^{6}$ CG 22057; CG, 22057; CG 22144; CG 22148.

${ }^{7} \mathrm{CG} 22147$.
} 
- I I R $n b$ stwt wbn m 3ht i3btt nt pt R` psd.k m hr n wsir $N N^{l}$.

- 'I R $n b$ stwt wbn $m$ [3ht] i3btt nt pt $R^{\top}$ psd.k $m$ [hr wsir $\left.n N N\right]^{2}$.

- dw3 Re-Hr-3hty nb stwt wbn n.fm 3ht i3btt nt pt pse n.k $m$ hr wsir $N N^{3}$.

- This line is omitted in some cases ${ }^{4}$.

(j) Kamal transcribed in his catalogue this portion as: [ $\star * w^{\circ}$ ], but the original text is coming without the signs of $d w 3$.

(k) As displayed on the parallel texts, there are significant differences come as:

- $\quad 33 w . t w R{ }^{e}-H r[m] d w 3 w$ shtp.tw $[m]$ mšrw pr b3 $n$ wsir $N N^{5}$.

- $\quad d w 3 . f t w m d w 3 w$ shtp. ftw m mšrw pr b3 $n$ wsir $N N^{6}$.

- In one case the artist omitted the name of the deceased in $p r b 3 n$ wsir $N N$ and used a reflexive suffix pronoun $f$ and goes ahead to the next sentence as: $d w 3$. $f m d w 3 w$ shtp $m$ mšrw $p r$ b3.f $r$ hn $n^{\top} . k r p t^{7}$.

- This line is used as introductory formula in CG 22145. Also $p r b 3 n w s i r$ $N N$ came after $3 b h$ ih $m w w r d^{8}$.

(1) Based on the parallel texts three orthographies are observed for this word as:

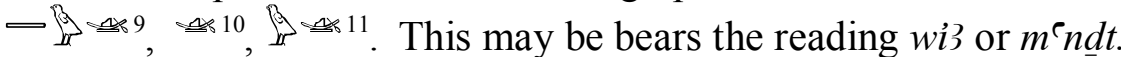

(m)Kamal's catalogue provided this sign ${ }^{ل}$ in $m n i$ but it is not existed in the original text. This sign is clearly shown in CG 22057, CG 22144 and CG 22146.

(n) With regard to CG CG 22057, CG 22144 this completion is supported.

(o) There are little variations can be observed in this line as:

- hn ${ }^{\top} . k r p t$ wd.tw $m$ wi3 mni m msktt 3bh.f $m$ ihmw wrd $m p t^{12}$.

- $\quad h n^{\top} . k r p t w d$ m wis mni m msktt 3bh.f $m$ ihmww wrd [ the artist omitted $m p t$ ]$^{13}$.

- $\quad h n^{\top} . k r p t w d \underline{d} m$ wỉw $n b h h^{14}$.

- $\quad h n^{\complement} . k r p t h \underline{d} m$ wỉ mni $m$ wnn imntt ${ }^{l 5}$.

(p) The seat sign (Q1) and the owner's name are completely worn away, but Kamal provided it as: []

(q) The section is completely destroyed, but kamal's catalogue provided as:

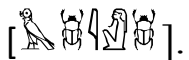

(r) The considerable number of parallels provide some variations as:

- $\quad$ dd.f sw3š nb.i nb r nhhh ind hr.k Re-Hr-3hty Hpri hpr ds. $f^{16}$.

- ind $h r . k[R]-H r-3 h t y \dot{H} p r i \grave{h p r} d s . f^{f^{\circ}}$.

${ }^{1}$ CG 41017.

${ }^{2}$ CG 22142.

${ }^{3}$ CG 22145.

${ }^{4}$ CG 41001 .

${ }^{5}$ CG 22057.

${ }^{6}$ CG 22144; CG 41001.

${ }^{7} \mathrm{CG} 221147$.

${ }^{8} \mathrm{CG} 22145$.

${ }^{9}$ The current stela line 4 .

${ }^{10} \mathrm{CG} 22144$.

${ }^{11}$ CG 22057; CG 22146.

${ }^{12}$ CG 22057.

${ }^{13} 22144$.

${ }^{14}$ CG 22145.

${ }^{15} \mathrm{CG} 22146$.

${ }^{16}$ CG 41001 .

${ }^{17} \mathrm{CG} 41002$. 
- $\quad$ in CG 22145 this artist adds after ind hr.k $R^{e}-H r$-3hty Hpri hpr $\underline{d}$ s.f a new sentence comes as: $\underline{d} d . f s w 3 \check{s} m$ stwt.k $n t r w n b w^{l}$.

(s) Two exceptions are noted for this line as: $n f r . w y$ wbn.k $m$ [3ht]. $k$ shd. $k$ t3wy $m$ stwt. $k^{2}$.

(t) The section is completely destroyed, but kamal's catalogue provided as:

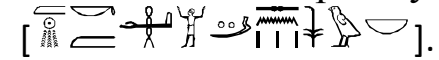

(u) Some differences can be observed in this line as:

- $\quad n t r w n b w m h^{\top e}$ m33.sn nswt $m$ pt $n b$ wnw.tw mnt $m$ tp. $k^{3}$.

- ntrwnbw he๔ m33.sn nsywt.k r pt? wnwt mn.tw hn $n^{\top} . k r t 3^{4}$.

- ntrw nbw m he m33.sn nsywt n.k wnwt mn.tw m tp.k ${ }^{5}$.

- ntrw nbw m hִ he htp m33.sn nswt $n$ pt nb wnwt mnt.ti $m$ tp.k ${ }^{6}$.

(v) This completion is given by kamal as: [

(w) A significant differences are noted in this line as:

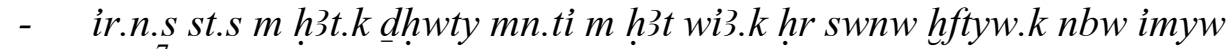
$d w 3 t^{7}$.

- 'Iw ir.s st.s $m$ h3t.k dhwty mnti $m$ h3t wi3[.k $]^{8}$.

- in CG 22147 Djeheuty is omitted and his task of guarding the sun boat is linked to the urea as: ir.s st.s $m$ h3t.k $m$ wi3.k hr swnw hftyw.k $[n b w]^{9}$.

- dhwty ikm wi3.k hr sirn hftyw. $\dot{k}^{10}$.

(x) The signs of $i m y w$ are given by Kamal as: [ [

(y) A Little completion of this line comes as: $h s f . k r m 33 s s ̌ m . k p w n f r^{11}$.

\section{Conclusions}

Certainly Hor is an extremely common name that is not informative, but his mother's name Weteth is not at all common. His mother name may be a significance key to determine him and his family but unfortunately it was given for one time in our stela and it seems that her name was not widespread. No other sources register this name again as it listed in Ranke. Also this name is provided in a unique case in the Akhmim stelae.

By examining eleven documents of the $15^{\text {th }}$ chapter of the Book of the Dead, versions $15 \mathrm{a}$ and $15 \mathrm{~b}$, existed in eight stelae from Akhmim and four sarcophagus from Thebes, it has become clear that there are significant differences of interest can be observed during the Ptolemaic area. With regard to the introductory formula, there are two verbs invoked the sun god. The first one is $i$, , 值 which means "to say" and it is only used to adore Re while the other one is $d w 3 \times$ which means "to adore" is exclusively linked with Re-Horakhety. Also a minor variation can be noted regarding the absence or the presence of $n$ of past as $w b n m$ 3ht or wbn $n . f m$ 3ht. Furthermore three variations can be seen while invoking the sun god to shine on the face of the

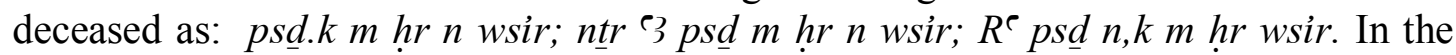

\footnotetext{
${ }^{1}$ CGG 22145.

${ }^{2}$ CG 41001; CG 241002.

${ }^{3} \mathrm{CG} 22025$.

${ }^{4}$ CG 22143.

${ }^{5}$ CG 22145.

${ }^{6} \mathrm{CG} 41002$.

${ }^{7}$ CG 22025.

${ }^{8}$ CG 22145.

${ }^{9} \mathrm{CG} 22147$.

${ }^{10}$ CG 22143.

${ }^{11}$ CG 22144.
} 
two sentences $d w 3$.. $m d w 3 w / s h t p . . m$ mšrw, two ways are used as $d w 3 . f$ tw / shtp.f $t w ; i 3 w . t w / s h t p t w$. The next spell pr b3 $n$ wsir $N N h n^{\top} . k r p t$ is a fixed formula in all stelae and sarcophagus except one case ommited the name of the deceased and referred to him by using the reflexive suffix pronoun $f$. Also $h n^{\top} . k r p t$ is omitted and followed by $3 b h \mathrm{~h}$ ihmw wrd. In $w \underline{d} m m^{`} n \underline{d} t$ mni $m$ msktt, the artist sometimes omitted the two terms $m^{\top} n \underline{d} t$ and $m s k t$ and used one word referring to them as wijw $n b n h \underline{h}$ as a sort of summarization. Alternatively $w \underline{d} / w d i / h \underline{d}$ are usually used by the artists. Also di.kr pt is used instead of $h n^{c} . k r p t$. With regard to the different parallels of the spell $\underline{d} d$. $f s w 3 \check{s}$ nb.i /.f $r h h$, it become clear that it was not a fixed formula and the context may begin with ind hr.k Re-Hr-3hty Hpri hpr $\underline{d} s . f$. Alternatively nswt / $n s y w t$ are frequently used in m33.sn $n s w t m p t n b$. Also three kind of preposition are noted in this sentence as $r p t ; m p t ; n p t$. with regard to all variations that provided to the last line it seems that the artist can omitted the speech of Djehwty and linked it to Isis who has the same role of guarding as ir.s st.s $m$ ḩt.k $m$ wỉ.k hr swnw hftyw.k.

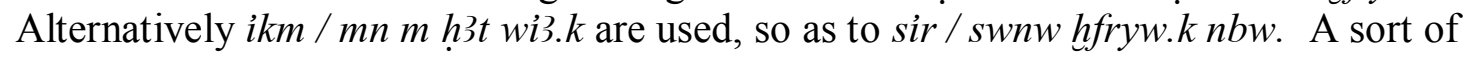
completion is noted by following $r m 33 s s ̌ m . k$ with $p w n f r$.

By surveying all vignettes of the previous documents, it become clear that the main scene is depicting the deceased adoring some standing deities comes in CG 22025 as: Min, Osiris, Horus, Nephthys and Anubis [fig 3] . In CG 22114 the deceased is shown in a double symmetric scene before two groups of deities. The right one is Min, Horus and Hathor while the second group is Re-Horakhty, Osiris and Isis [fig 4]. In CG 22057 the deceased stands in adoration pose before Osiris, Isis and Nephthys in the right side and before Amun, Re-Horakhty and Anubis in the left side[fig 5] ${ }^{1}$. With regard to Stele London BM EA 711, the deceased is depicted in adoration pose before a row of deities as Osiris, Horus, Anubis, Hathor, Isis and Nephthys [fig 6]. In CG 22144 a significant differences is that the adoring god is shown sitting on the throne and a group of protective demons are shown among Osiris, Horus, Anubis and Nephthys.

By examining these documents, some results can be observed as follows:

- Adoration before standing deities was the main scene on the stelae.

- The stelae's owners were commonly shown in adoration pose by rising their arms with a slender offering table containing one vessel and flower before them.

- Osiris is shown holding the crook and the flail or the the usual $w 3 s$-sceptre with the crook and the flail.

- $\quad$ in the double symmetric scene the deceased adores three deities in the right and the same number in the left.

- The main adoring deities are Osiris, Isis, Nephteth and Anubis.

\footnotetext{
${ }^{1}$ See S. P.Vleeming, A Hieroglyphic-Demotic Stela from Akhmim, in: Hoffmann, F.; Thissen, H. J. (Hg.), Res severa verum gaudium. Festschrift für Karl-Theodor Zauzich zum 65. Geburtstag am 8. Juni 2004, (Leuven : Dudley, Mass.;Peeters, 2004.), 623-637, Abb. LVIII.
} 
Figures

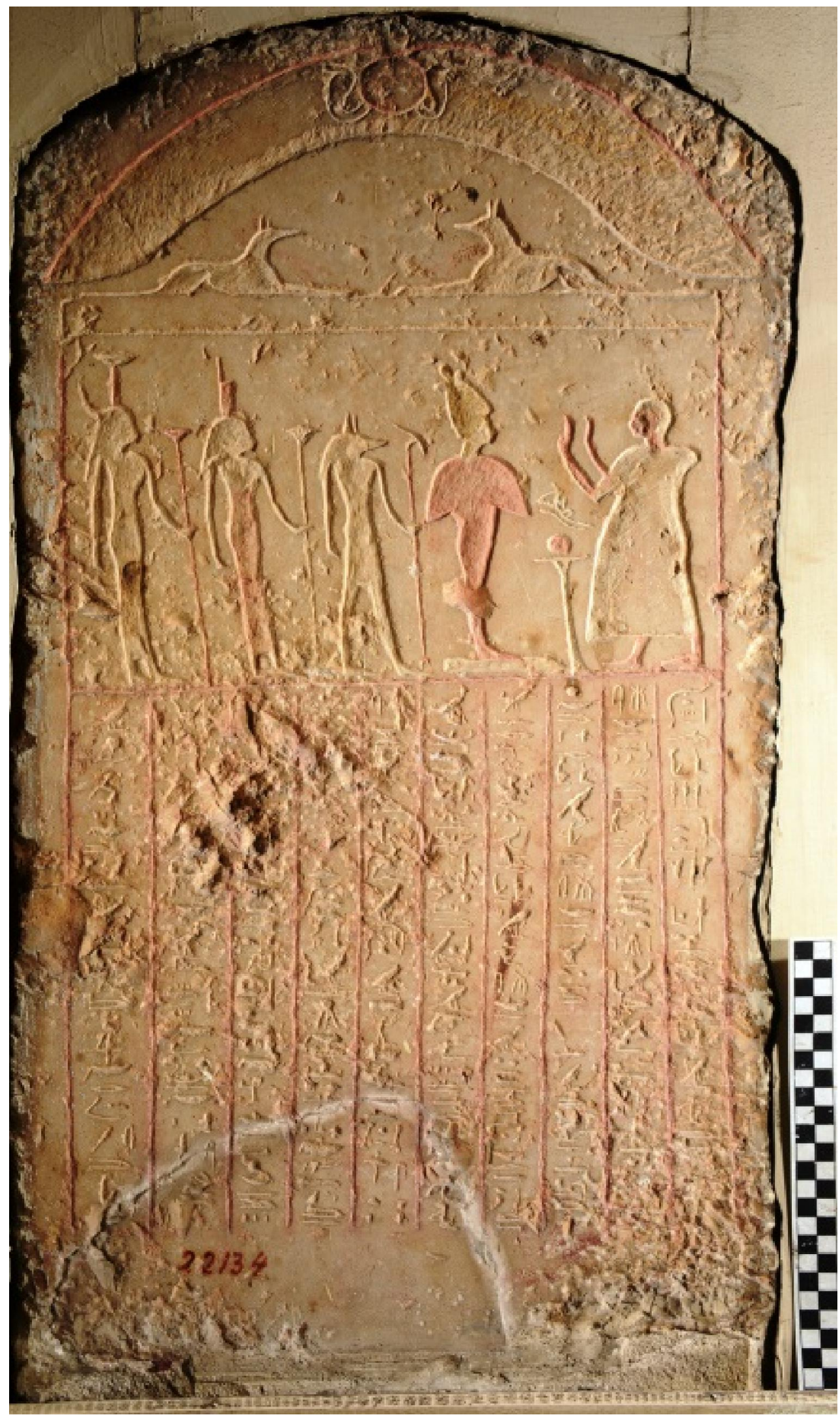

Figure (1a) Photograph by the author 


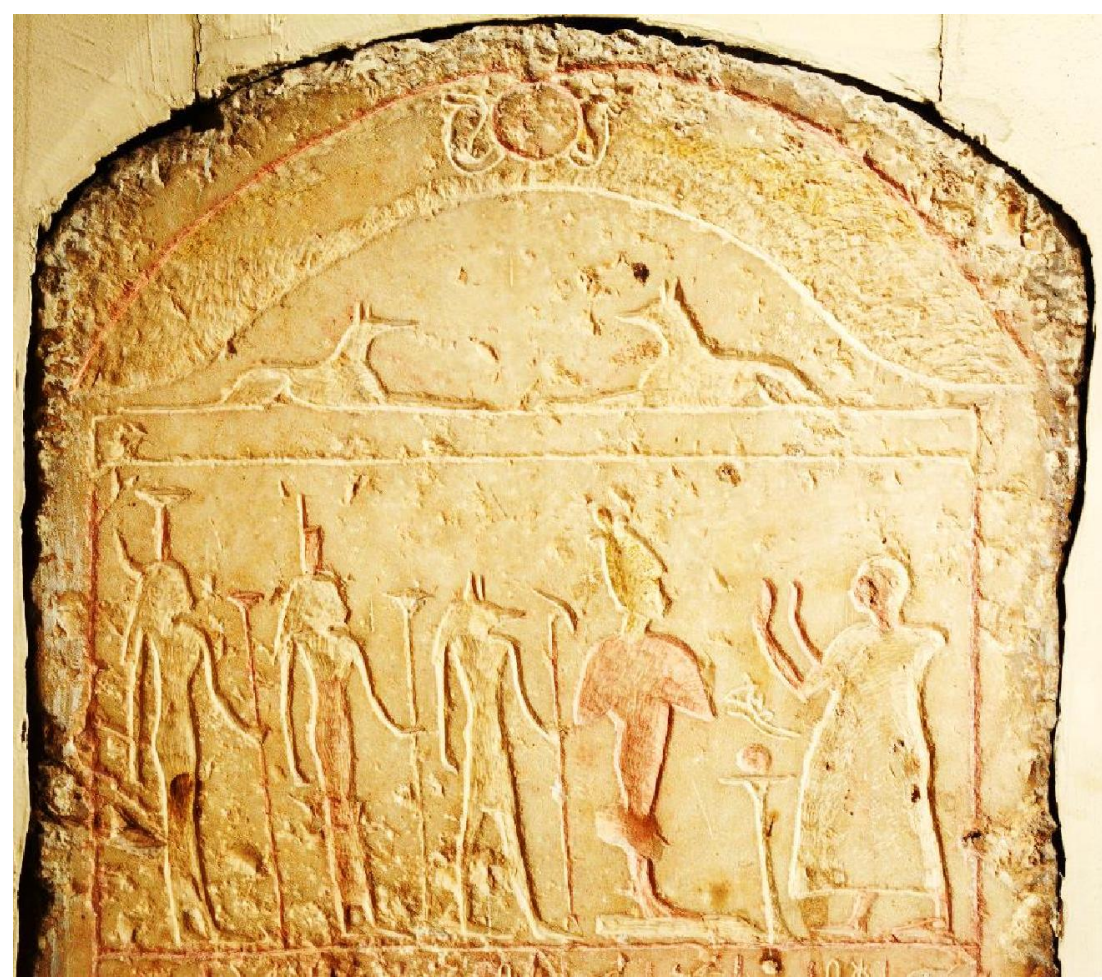

Figure (1b) Photograph by the author

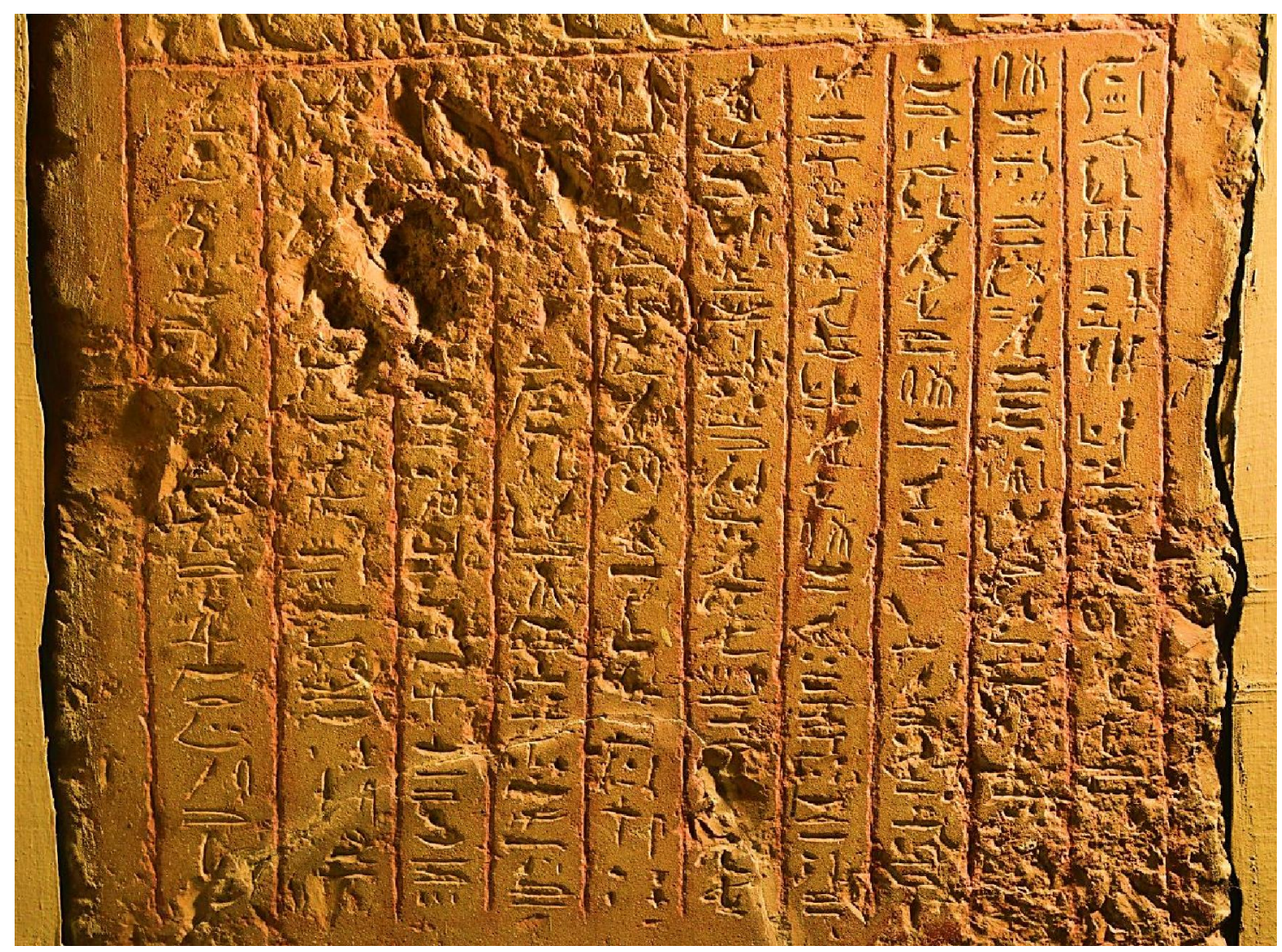

Figure (1c) Photograph by the author 


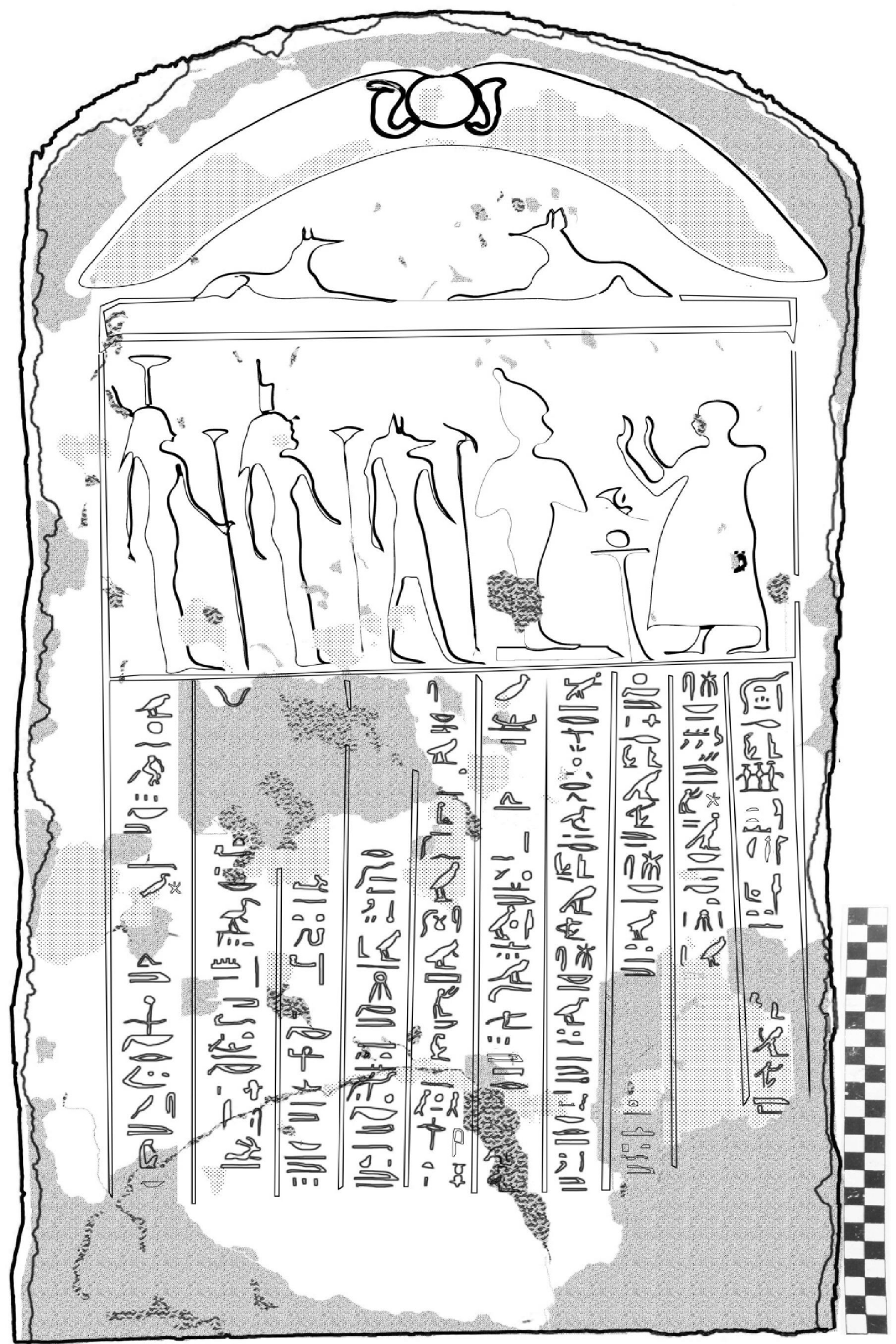

Figure (2) Illustrated drawing by Mohammed, S 


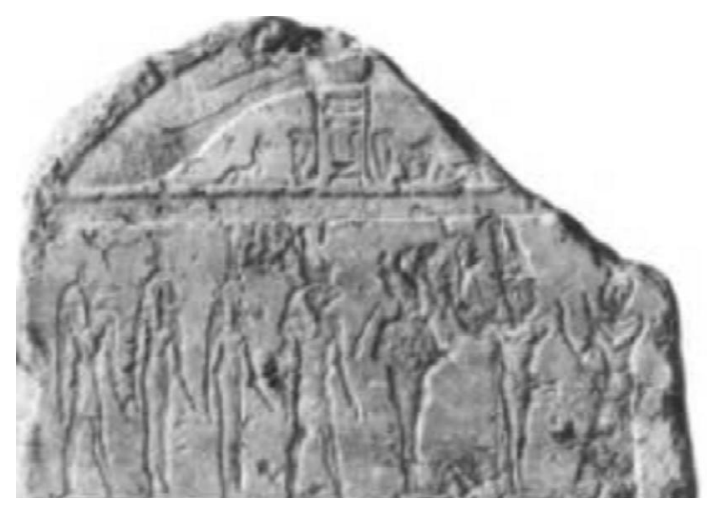

Figure (3) CG 22025, Kamal, A., Catalogue général des antiquités égyptiennes, II, PL IX.

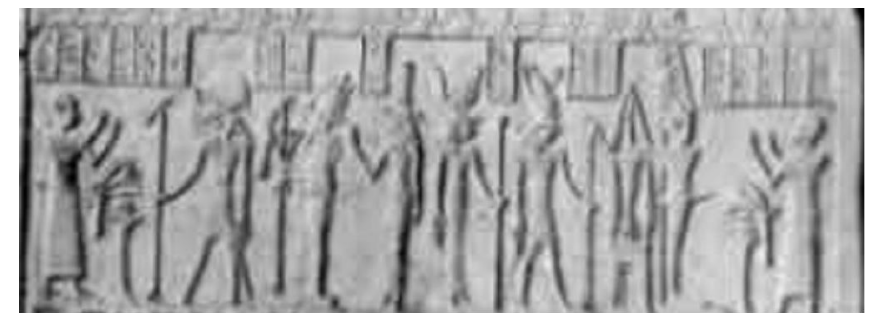

Figure (4) CG 22114, Kamal, A., Catalogue général des antiquités égyptiennes, II, PL XXXIV.

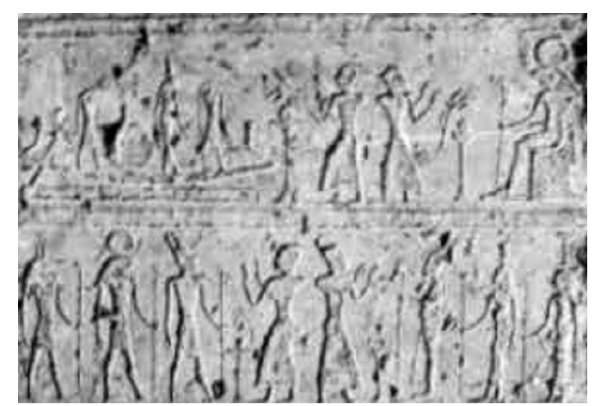

Figure (5) CG 22057, Kamal, A., Catalogue général des antiquités égyptiennes, II, PL IX.

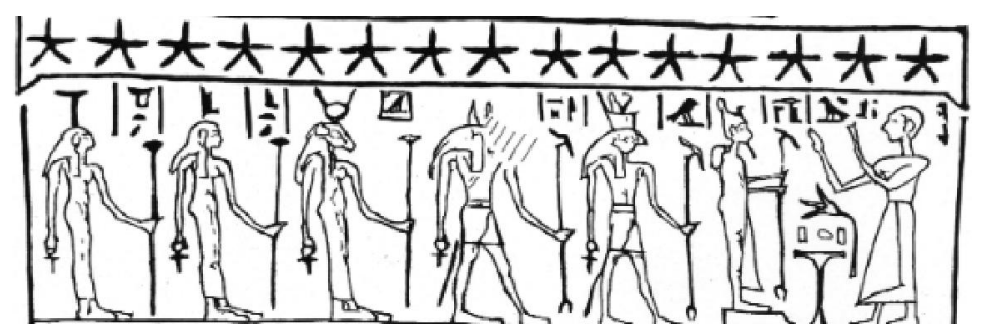

Figure (6) see Vleeming, S. P., A Hieroglyphic-Demotic Stela from Akhmim, Abb. LVIII. 


\section{REFERENCES}

1- Bothmer, B. V., "A New Fragment of an Old Palette", JARCE, 8 (1969): 5-8

2- Erman, A. \& Grapow, H., Wörterbuch der ägyptischen Sprache, Die Belegstellen, 6 Bde, Berlin und Leipzig, 1926-63.

3- Kamal, A., Catalogue général des antiquités égyptiennes du Musée du Caire $N^{\circ} 2200122208$ Stèles ptolémaïques et romaines, Texte I-II, Cairo:IFAO, 1905

4- Lichtheim, M., "The Stela of Taniy CGC 20564: Its Date and its Character", SAK, 16 (1989): 203-215.

5- Mosher, M., The Book of the Dead, Saite through Ptolemaic Periods: A Study of Traditions Evident in Versions of Texts and Vignettes, Volume 1 (BD Spells 1-15), United States: CreateSpace Independent Publishing Platform, 2017.

6- Munro, P., Die spätägyptischen Totenstelen, ÄgForsch 25, vol. I, Germany: Verlag J.J. Augustin, Gluckstadt, 1973.

7- Ranke, H., Die ägyptischen Personennamen, I, German : Glückstadt: J.J. Augustin, 1935.

8- Russman, E.R, The Representation of the King in the XXVth Dynasty, Brooklyn: Bruxelles, Fondation égyptologique Reine Élisabeth, 1974.

9- Vleeming, S. P., "A Hieroglyphic-Demotic Stela from Akhmim", in: Hoffmann, F.; Thissen, H. J. (Hg.), Res severa verum gaudium. Festschrift für Karl-Theodor Zauzich zum 65. Geburtstag am 8. Juni 2004, Leuven : Dudley, Mass.;Peeters, 2004..

10- http://totenbuch.awk.nrw.de/account/registrieren.. 